\title{
Piecing the Puzzle of the "Shameful Intercourse": How Polyphony Serves Healing in Caryl Phillips's Crossing the River
}

\author{
Brahimi Sarra \\ University of Badji Mokhtar Annaba, Algeria \\ Faculty of Letters, Social and Human Sciences \\ Department of English \\ Maoui Hocine \\ University of Badji Mokhtar Annaba, Algeria \\ Faculty of Letters, Social and Human Sciences \\ Department of English
}

\begin{abstract}
:
This article explores the polyphony as a narrative strategy in Caryl Phillips's Crossing the River 1993 and how this polyphony serves the healing process the author engages in through his revision of history that thematizes black slavery as a key episode in black modern history. Phillips, the Kittitian-British author, interweaves a variety of narrative voices of both black and white characters in an attempt to provide a thorough scrutiny and a deep diagnosis of a traumatic past that contains the underlining fundaments of present racial issues and identity dilemmas that black communities suffer from in both the United States and Britain. This study is primarily focused on deconstructing and reconstructing Phillips's portrayal of what he calls "the shameful intercourse" between the slave trader and the African father. The aim of this analysis is to uncover the author's polyphonic strategy that equally voices both the "white" and the "black", "the oppressor" and "the oppressed". This rather experimental study allows us to understand how polyphony is used to serve reconciliation and healing.
\end{abstract}

Keywords: diaspora, healing, polyphony, slavery, trauma

Cite as: Brahimi, S., \& Maoui, H. (2018). Piecing the Puzzle of the "Shameful Intercourse": How Polyphony Serves Healing in Caryl Phillips's Crossing the River. Arab World English Journal for Translation \& Literary Studies, 2 (2).

DOI: http://dx.doi.org/10.24093/awejtls/vol2no2.15 